\title{
Conophthorin from Almond Host Plant and Fungal Spores and Its Ecological Relation to Navel Orangeworm: a Natural Products Chemist's Perspective
}

\author{
John J. Beck* \\ Plant Mycotoxin Research, Western Regional Research Center, Agricultural Research Service, U.S. Department of Agriculture, \\ 800 Buchanan Street, Albany, CA 94710, United States; and, Department of Environmental Toxicology, University California, \\ One Shields Avenue, Davis, California, 95616, United States.john.beck@ars.usda.gov
}

Received: February 12, 2013; accepted: March 27, 2013

\begin{abstract}
The navel orangeworm (Amyelois transitella) is a major insect pest that brings about significant monetary damage to California tree nuts - almonds, pistachios, and walnuts. During their development, larvae of navel orangeworm feed upon the meat of these nuts causing physical damage and ultimately lowering kernel quality. Moreover, the larvae have been purported to vector aflatoxigenic fungi into the food product and thus represent a serious food safety concern. Aflatoxins are toxic metabolites produced by certain aspergilli - specifically for California tree nuts, Aspergillus flavus and Aspergillus parasiticus. Volatiles have played a large role in efforts to control or monitor navel orangeworm moths. For instance, a blend of almond host plant volatiles has recently been found to attract both male and female navel orangeworm moths during field trapping studies. The origin of many of the components within this host plant blend appears to be from the almond host. However, new reports regarding the blend component, conophthorin, imply a fungal origin for this particular volatile. This perspective discusses current investigations directly related to the production of conophthorin, and proposes a new relationship among navel orangeworm, the almond host plant, and ubiquitous tree nut orchard fungi.
\end{abstract}

Key words: Amyelois transitella, Aspergillus, conophthorin, fungal spores, navel orangeworm, spiroketal.

\section{Introduction}

The spiroketal conophthorin (Figure 1), 7-methyl-1,6-dioxaspiro $[4,5]$ decane, has recently been identified as an important component in a blend of host plant volatiles capable of attracting male and female navel orangeworm moths [1]. The report of conophthorin's semiochemical behavior to navel orangeworm adds to the rich history of conophthorin as a bark beetle semiochemical [2] and as a bark beetle non-host plant volatile [3]. In addition to its new role as a key component for navel orangeworm attraction, our laboratories have recently reported the production of conophthorin from fungal spores on common fatty acids common to orchards and which play host to navel

Editorial note. This account is part of the plenary lecture presented by Dr. John J. Beck at the Symposium on Natural Products Chemistry, 30th Latin American Chemical Congress, held in Cancún, Quintana Roo, México, October 27-31, 2012.
Resumen. El gusano de ombligo naranja (Amyelois transitella, también conocido como polilla del nogal) es una peste que produce un gran daño a los árboles de nueces, almendras y pistache en California. Durante su desarrollo, las larvas de la polilla se alimentan de los frutos, causando un daño físico importante y bajan su calidad, con las respectivas pérdidas económicas. Más aún, se ha propuesto que las larvas sean el vector de hongos que producen aflatoxinas, por lo que este fenómeno constituye un reto a la seguridad alimentaria. Las aflatoxinas son metabolitos tóxicos producidos por varias especies de Aspergillus, específicamente Aspergillus flavus y A. parasiticus para los nogales de California. El estudio de las substancias volátiles ha jugado un papel importante en el seguimiento del desempeño del gusano de ombligo naranja. Por ejemplo, se ha encontrado recientemente, mediante un estudio de atrapamiento en el campo, que una mezcla de los volátiles de la planta de almendras como anfitrión atraen tanto a los machos como a las hembras de las polillas del gusano. El origen de la mayoría de los componentes en esta mezcla de la planta anfitrión parece ser la propia almendra. Sin embargo, nuevos reportes referentes a uno de los componentes volátiles, la conoftorina, implican el origen fúngico de esta substancia en particular. Esta perspectiva discute las investigaciones actuales enfocadas a la producción de la conoftorina y propone una nueva relación entre el gusano de ombligo naranja, la planta anfitrión de almendra y los hongos ubicuos de un huerto de nogales.

Palabras clave: Amyelois transitella, Aspergillus, conoftorina, esporas de hongos, gusano de ombligo naranja, espirocetal.

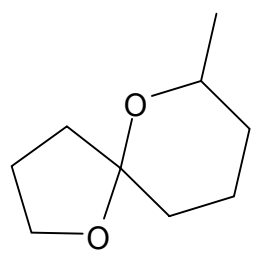

Fig. 1. The spiroketal conophthorin, 7-methyl-1,6-dioxaspiro[4,5] decane; an important component of a host plant volatile blend that attracts navel orangeworm, and also a volatile emitted by fungal spores ubiquitous in California tree nut orchards.

orangeworm infestations [4]. A prelude to the report of conophthorin production from fungal spores was its detection from almond hulls, but not pistachios hulls, and possible relation to the water activity of the hulls [5]. The association of spiroketal emission with the water activity of the host provided support to the relationship between conophthorin and fungal spores. 
The relationship of navel orangeworm, aflatoxins, and California tree nuts

Beck and Higbee [6] have recently provided an overview of natural products and their role in monitoring the navel orangeworm in California tree nut orchards. In their report, they provide a brief history of the navel orangeworm, its origin and movement into California tree nuts. Important to note is the observed relationship between navel orangeworm and the aflatoxigenic fungi, Aspergillus flavus and A. parasiticus. Literature cited within the report describes the association of navel orangeworm and aflatoxin contamination within almonds [7, 8], pistachios [9], and walnuts [10]. In 2008 Palumbo and coworkers [11] reported experimental evidence of navel orangeworm larvae vectoring spores of aspergilli over agar media. In 2011 Berenbaum and co-workers [12] demonstrated that the polyphagous navel orangeworm larvae were capable of detoxifying the toxins produced by aflatoxigenic aspergilli and thus developed in an otherwise toxic environment. Depending on temperature, relative humidity, and host, navel orangeworm can undergo ca. six larval instars over ca. 43 days, and pupate for ca. seven days [13]. Because navel orangeworm larvae spend a significant portion of their lives within the confines of almond, pistachio, or walnut hull, and the high incidence of aflatoxigenic fungi within these confines, there exists a perfect opportunity for larvae to associate the emitted volatiles as home - a safe and secure place to develop through pupation $[13,14]$. Explored in this perspective is the apparent relationship among navel orangeworm, fungi, and almond as the host plant.

\section{Conophthorin from the almond host plant}

In 2008 conophthorin was reported from ex situ damaged and undamaged almonds in addition to the spiroketal chalcogran [15]. Until this report, conophthorin was primarily associated with the bark beetle as a repellant emitted by non-host angiosperm trees [16-18] or from several scolytids, wasps, and fruit fly [16].

At the time of its detection from ex situ almond host volatile emissions [15] there was some initial interest in the compound as a possible semiochemical to navel orangeworm. This was in part due to its unique structure relative to typical almond volatiles, but also due to its history as a semiochemical for other insects. The initial interest in conophthorin was dampened, however, by its poor electroantennographic (EAG) bioassay results observed by our laboratory and accordingly attention was turned to other promising candidate compounds. It should be noted that EAG analyses carried-out in our laboratories at that time were subjected to fairly stringent correction factors due to a lack of a female navel orangeworm electrophysiological positive standard $[1,19]$. Since then our laboratories have adapted a rapid, high-throughput, and standardized EAG method for screening volatiles using navel orangeworm antennae [20], and have applied this technique to ca. one hundred compounds emitted from both almonds and pistachios (paper forthcoming).
Congruently, in 2008 our laboratories were investigating a modified collection method that allowed for the collection of in situ volatiles from almonds undergoing hull split - naturally damaged almonds. Our laboratory's interest in damaged tree nuts arose from earlier observations that navel orangeworm were attracted to injured almonds [21, 22]. The 2008 in situ hull split volatile collection resulted in several compounds taken on for intensive EAG studies and field trapping studies over the next three years [1]. Among the volatiles collected, conophthorin was detected and interest in this compound was re-invigorated. As a result, conophthorin was subjected to assays via EAG analysis and field trapping studies. Individually, conophthorin did not elicit remarkable activity from navel orangeworm antennae or moths, respectively, but when added to the other host plant volatile blend components being considered [1], conophthorin greatly enhanced the trap capture efficacy of the blend.

Returning to the 2008 report on mechanically damaged almonds [15], it was observed that several volatiles indicative of fungal growth were detected in the headspace of the almonds - for example 2-pentyl furan, 1-octen-3-ol, and other small, branched alcohols. Subsequent and prior studies involving almond and pistachio volatile analysis demonstrated that the detection of conophthorin from almonds was ephemeral. The indication of fungal presence provided further impetus to explore the idea that perhaps fungi on almonds produced conophthorin. For instance, an investigation of the volatile emissions from almond and pistachio hulls [5] established a link between the water activity $\left(\mathrm{a}_{\mathrm{w}}\right)$, in this instance the status of water available for fungal growth, and the production of conophthorin. In their report [5], Beck and co-workers were able to consistently reproduce the generation and detection of conophthorin from almond hulls and shells. Important to note from this study was that conophthorin was detected when no visible fungal growth was present. However, once fungal growth was observed by the naked eye, conophthorin production halted and the remaining volatile profile decreased substantially.

\section{Conophthorin from fungal spores}

With the link between $\mathrm{a}_{\mathrm{w}}$ and almond hulls supporting the idea that conophthorin was produced by fungi [5], attention was turned to fully proving the hypothesis. Because conophthorin production was noted during early fungal development, the idea to evaluate fungal spores was pursued. Earlier work by other researchers with Penicillium spp. had demonstrated that spores were capable of emitting a wide range of volatiles [23, 24]. Because the navel orangeworm is a serious insect pest to both pistachio and almond, and these two commodities have similar fatty acid profiles, the decision was made to prove the hypothesis at the most basic level using single fungal spores on individual fatty acids common to both tree nut commodities [4].

The most interesting result from the study of fungal spores on fatty acids [4] was that conophthorin, along with the chalcogran isomers, was produced when the spores were placed on 
linoleic acid, the 9,12-diene C18 acid; whereas only the chalcogran isomers were produced when the spores were placed on linolenic acid, the 9,12,15-triene C18 acid. None of the tested fungal spores when placed on either the monoene or the fully saturated fatty acids, oleic and palmitic, respectively, produced any conophthorin.

The evidence provided by the fungal spores study [4] proved conclusively that the tested spores produced conophthorin. However, the same certainty cannot yet be applied as to whether an almond matrix on its own can, or cannot, produce conophthorin. The almond hull study [5] provided strong evidence that conophthorin is produced in the hulls. Correspondingly, the $\mathrm{a}_{\mathrm{w}}$ supported the hypothesis of fungal spores on hulls were responsible for conophthorin production. The strongest evidence for this supposition was when the $\mathrm{a}_{\mathrm{w}}$ of the split hulls fell below the documented $\mathrm{a}_{\mathrm{w}}$ levels for xerophilic aspergilli, and no conophthorin was detected [5]. Aspergillus niger requires a minimum $\mathrm{a}_{\mathrm{w}}$ value of 0.77 , and A. flavus and A. parasiticus require a minimum $\mathrm{a}_{\mathrm{w}}$ value of 0.80 for growth. Comparatively, most fungi require an $\mathrm{a}_{\mathrm{w}}$ value of more than 0.85 for growth [25]. However, re-hydration of the hull material ultimately resulted in conophthorin production - presumably after the $a_{w}$ content of the hulls reached a value greater than 0.77 or 0.80 .

\section{Conophthorin as the common component}

In terms of navel orangeworm infestation in almonds, the studies discussed above may be presenting evidence for a heretofore-unknown yet intricate relationship [26] among navel orangeworm, the almond host plant, and ubiquitous tree nut orchard fungi (Figure 2). A review of the evidence includes the following: 1) navel orangeworm neonates have been shown to vector aspergilli spores into the hulls of the tree nuts [11];

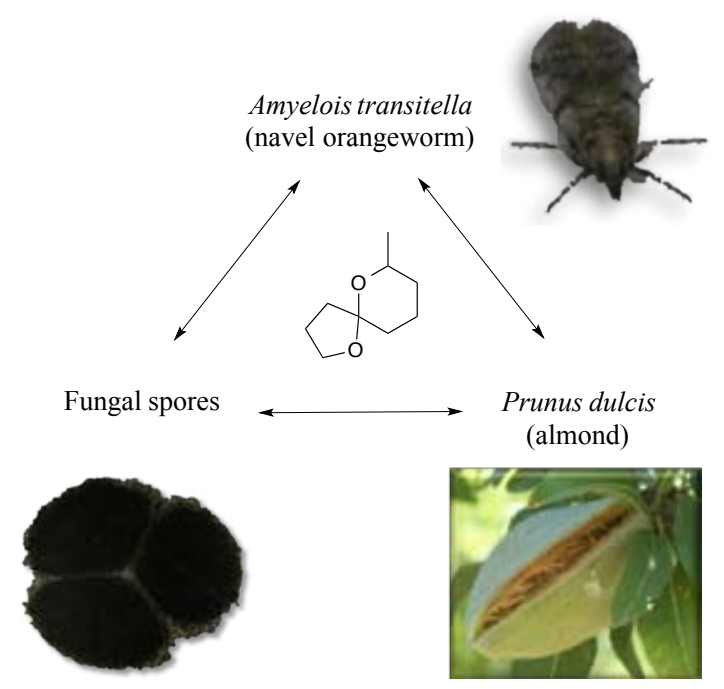

Fig. 2. Schematic showing postulated relationship of navel orangeworm, fungal spores, and almonds as a host plant to navel orangeworm. The spiroketal conophthorin shown in the middle is the common component to the relationship.
2) the navel orangeworm is polyphagous, meaning it feeds on many different host plants and many types of food. Navel orangeworm larvae are also known to detoxify aflatoxin [12], a product of aflatoxigenic fungi, thus implying the larvae are able to ingest aspergilli in addition to different host plants; 3 ) navel orangeworm larvae spend ca. 50 days [13] within the confines of the hull and are constantly exposed to the volatiles produced by any spores transported into the hull by the neonates; 4) fungal spores produce conophthorin, among others, when in the presence of hull material (e.g. the fatty acid linoleic acid); 5) adult navel orangeworm moths, both male and female, are attracted to a blend of volatiles comprised of conophthorin and other compounds emitted during almond hull split; and, 6) the almond hull split phenological stage is considered a vulnerability to navel orangeworm infestation [27].

This evidence would suggest that the adult navel orangeworm has learned to distinguish these odors as "home" and is able to respond to the volatiles produced by fungal spores on a suitable host. If conophthorin is truly a product of fungal spores on the almond host, does the navel orangeworm associate fungal spore emissions to a safe larval development environment? However, proof of this theory may not be straightforward. There has been seeming conflict in the literature over several years with respect to whether the behavior of an adult insect can be influenced by the odors it experiences as a larva. This theory, called the Hopkins' Host-Selection Principle (HHSP), was reviewed in 2001 [14]. The question of adult navel orangeworm adapting to the odors they were exposed to as developing larvae would need to be further explored via rigorous experimentation. It is conceivable that the question could be explored by placing neonates from wild navel orangeworm on normal diet, sterilized almond hulls, and inoculated almond hulls. After larval development under these treatments, the adult navel orangeworm could be subjected to electrophysiological and behavioral assays to ascertain whether or not their larval environments played a role in their adult responses to host plant and fungal volatiles.

The review of the HHSP provides many instances of experiments both for and against this principle [14]. A recent example cites that other polyphagous Lepidoptera moths have demonstrated a preference for host plant sources inoculated with certain endophytes [28]. Despite the unresolved questions regarding adult behaviors due to larval environments, as well as the questions raised in the discussion above, other questions regarding navel orangeworm and the recently discovered host plant and fungal volatiles remain: does the presence of conophthorin indicate a suitable host for the female to deposit her eggs, along with a suitable moisture level needed for larval development; and, moreover, does the presence of aflatoxigenic fungi possibly provide a form of protection from predators or other competition?

\section{Conclusions}

Two recent discoveries regarding the spiroketal conophthorin bring about new questions regarding the chemical communi- 
cation of the agricultural insect pest navel orangeworm. The fungal spore origin of conophthorin has been confirmed and the role of the almond host plant is undergoing intensive investigation. Correspondingly, conophthorin has been identified as an essential ingredient of an almond host plant volatile blend reported to attract adult navel orangeworm moths. To fully investigate this new chemical ecology relationship, experiments involving multiple disciplines will need to be performed in an integrated approach [26], with natural products chemistry playing a small, yet vital role.

\section{Acknowledgements}

The monumental research efforts of current and past group members are gratefully acknowledged, in particular Noreen Mahoney, Wai Gee, Gloria Merrill, Jennifer Hayashi, and Nausheena Baig.

\section{References}

1. Beck, J. J.; Higbee, B. S.; Light, D. M.; Gee, W. S.; Merrill, G. B.; Hayashi, J. M. J. Agric. Food Chem. 2012, 60, 8090-8096.

2. Francke, W.; Kitching, W. Curr. Org. Chem. 2001, 5, 233-251.

3. Shepherd, W. P.; Huber, D. P. W.; Seybold, S. J.; Fettig, C. J. Chemoecology 2007, 17, 209-221.

4. Beck, J. J.; Mahoney, N. E.; Cook, D.; Gee, W. S. J. Agric. Food Chem. 2102, 60, 11869-11876.

5. Mahoney, N. E.; Gee, W. S.; Higbee, B. S.; Beck, J. J. Phytochem. Lett. 2013, http://dx.doi.org/10.10116j.phytol.2013.03.004.

6. Beck, J. J.; Higbee, B. S.; Light, D. M.; Gee, W. S.; Merrill, G. B.; Hayashi, J. M. 244 ${ }^{\text {th }}$ American Chemical Society National Meeting, August 19, 2012; and in a forthcoming book chapter, Beck, J. J.; Higbee, B. S. ACS Symposium Book Series: in Natural Products for Pest Management.
7. Schatzki, T. F.; Ong, M. S. J. Agric. Food Chem. 2001, 49, 45134519.

8. Higbee, B. S.; Siegel, J. P. Calif. Agric. 2009, 63, 24-28.

9. Doster, M. A.; Michailides, T. J. Phytopathology 1994, 84, 583590.

10. Campbell, B. C.; Molyneux, R. J.; Schatzki, T. F. J. Toxicol. Toxin Rev. 2003, 22, 225-266.

11. Palumbo, J. D.; Mahoney, N. E.; Light, D. M. Phytopathology 2008, 98, S119.

12. Niu, G.; Rupasinghe, S. G.; Zangerl, A. R.; Siegel, J. P.; Schuler, M. A.; Berenbaum, M. R. Insect Biochem. Mol. Biol. 2011, 41, 244-253.

13. Wade, W. H. Hilgardia 1961, 31, 129-171.

14. Barron, A. B. J. Insect Behav. 2001, 14, 725-737.

15. Beck, J. J.; Higbee, B. S.; Merrill, G. B.; Roitman, J. N. J. Sci. Food Agric. 2008, 88, 1363-1368.

16. Zhang, Q.-H.; Tolasch, T.; Schlyter, F.; Francke, W. J. Chem. Ecol. 2002, 28, 1839-1852.

17. Booth, Y. K.; Kitching, W.; De Voss, J. J. Nat. Prod. Rep. 2009, 26, 490-525.

18. Francke, W.; Bartels, J.; Meyer, H.; Schroder, F.; Kohnle, U.; Baader, E.; Vite, J. P. J. Chem. Ecol. 1995, 21, 1043-1063.

19. Beck, J. J.; Merrill, G. B.; Higbee, B. S.; Light, D. M.; Gee, W. S. J. Agric. Food Chem. 2009, 57, 3749-3753.

20. Beck, J. J.; Light, D. M.; Gee, W. S. J. Vis. Exp. 2012, 63, e3931.

21. Curtis, R. K.; Barnes, M. M. J. Econ. Entomol. 1977, 70, 395398.

22. Roitman, J. N.; Merrill, G. B.; Higbee, B. S. Proceedings of the 4th Fungal Genomics, 5th Fumonisin Elimination, and 17th Aflatoxin Elimination Workshop. Oct. 25-28, 2004; p 27.

23. Chalier, P.; Crouzet, J. Flavour Frag. J. 1993, 8, 43-49.

24. Park, O. -J.; Holland, H. L.; Khan, J. A.; Vulfson, E. N. Enzyme Microb. Tech. 2000, 26, 235-242.

25. Hocking, A.D. Fungal xerophiles (osmophiles). eLS. John Wiley \& Sons Ltd.Chichester, UK. 2001.

26. Beck, J. J. J. Agric. Food Chem. 2012, 60, 1153-1157.

27. Gradziel, T. M.; Martinez-Gomez, P. J. Amer. Soc. Hort. Sci. 2002, 127, 69-74.

28. Jallow, M. F. A.; Dugassa-Gobena, D.; Vidal, S. Arthropod-Plant Inte. 2008, 2, 53-62. 